\title{
Flood Height Measurement and Analysis in Parts of Obio/Akpor Local Government Area, Port Harcourt Metropolis, Nigeria
}

\author{
Nwankwoala H. O. ${ }^{1}$ \& Jibril T. ${ }^{1}$ \\ ${ }^{1}$ Department of Geology, University of Port Harcourt, Nigeria \\ Correspondence: Nwankwoala H. O., Department of Geology, University of Port Harcourt, Nigeria.
}

Received: May 25, 2019

Accepted: June 28, 2019 Online Published: July 1, 2019

doi:10.5539/emr.v8n2p1

URL: https://doi.org/10.5539/emr.v8n2p1

\begin{abstract}
This study was conducted on flood sensitive areas in parts of Obio-Akpor Local Government Area, Port Harcourt, Rivers State, Nigeria, in order to determine the impact of flood on the residents of the area. The method of study involved field work and laboratory analysis. Field studies involved flood height measurements. Flood heights monitored and measured over a period of one week was used to determine the flood daily encroachment rates and the flood daily receding rates. Flood encroachment rates ranged from 9.47 to $19.67 \mathrm{~cm} /$ day in Rumuigbo, and 6.47 to $9.00 \mathrm{~cm} /$ day in Ozuoba. Flood recede rates ranged from 0.87 to $3.93 \mathrm{~cm} /$ day and 5.00 to $8.00 \mathrm{~cm} /$ day in Rumuigbo and Ozuoba. These results were confirmed by the high annual rainfall $(2198.73 \mathrm{~mm} / \mathrm{hr}$ on average $)$ that occurs on average round the year in Rivers State. The buildings in these flood prone areas were constructed with concrete and blocks which are susceptible to cracking and failure when constantly immersed in water for prolonged time. It is therefore recommended that large sloping gutters be constructed within strategic places in the area in order to properly transport water to the nearby rivers and ensure that dumpsites around flood prone areas are evacuated to prevent contaminated water from recharging the aquifer.
\end{abstract}

Keywords: flooding, rainfall, height measurement, surface elevation, Obio/Akpor, Port Harcourt

\section{Introduction}

The study area is located within Port-Harcourt metropolis, Rivers State, Nigeria (Figure 1). The areas are bound geographically by latitudes $4^{\circ} 48^{\prime} 30^{\prime \prime} \mathrm{N}$ to $4^{\circ} 52^{\prime} 20^{\prime \prime} \mathrm{N}$ and longitudes $6^{\circ} 57^{\prime} 40^{\prime \prime} \mathrm{E}$ to $7^{\circ} 00^{\prime} 00^{\prime \prime} \mathrm{E}$ and The communities within the study areas are Ozuoba and Rumuigbo community. The area falls within the coastal belt dominated by low lying coastal plains which structurally belong to the sedimentary formations of Niger Delta (Chiadikobi et al., 2011).

Flood disaster is not a recent phenomenon in Nigeria. Its destructive tendencies are sometimes enormous. In Nigeria, flooding displaces more people than any other natural disaster with an estimated $20 \%$ of the population at risk (UNOCHA, 2015). It is difficult to determine the extent of flood damage and to compare in a satisfactory manner one flood with another, mostly due to the relative tendency to overestimate flood damage, particularly at the time of the event (Edmund, 2013). Flooding in Nigeria occurs in three main forms: river flooding, urban flooding and coastal flooding (Igbokwe et al., 2008). In Nigeria, flood occurrence can cause panic nationwide. Flood events have caused astronomical price hikes in food crops, resulting to an estimated $2 \%$ rise in rate of inflation (Onwuka et al., 2015). By far, this is the worst environment-induced economic disaster Nigeria faces. Flood impacts are often felt all over most parts of the country (Kolawole et al., 2011). In 2012, the government spent approximately US\$ 300 million on relief materials for flood victims (UNOCHA, 2012). In the face of flood disaster, predominately affecting about one quarter of the country's cities, many Nigerians are of the opinion flood events will not end, or get better anytime soon, leaving the general population with hope of government mitigation and adaptation resolve. Poor and unavailable flood prediction, flood control systems and techniques are seen as major causes that aggravate flood disaster nationwide.

Damage caused by flood to agriculture, homes and public facilities around the world runs into several millions of dollars annually. Hence, recent years have seen increased attention for strategic flood risk assessments, and their inclusion in global integrated assessments (OECD, 2012). The impacts and effects of flooding have also been noted to range from submerging roads, obstruction of traffic, coastal erosion, disruption of economic activities, displacement of people, loss of property, to loss of lives (Etuonovbe, 2011). 
Reduction of flood risks depends largely on the amount of information on floods that is available and knowledge of the areas that are likely to be affected during a flooding event (Jeb \& Aggarwal, 2008). This study therefore, was conducted on flood sensitive areas in parts of Obio-Akpor Local Government Area, Port Harcourt, Rivers State, Nigeria, in order to determine the impact of flood on the residents of the area. This study will support decision makers develop better planning measures on how to manage flood incidents in the area.

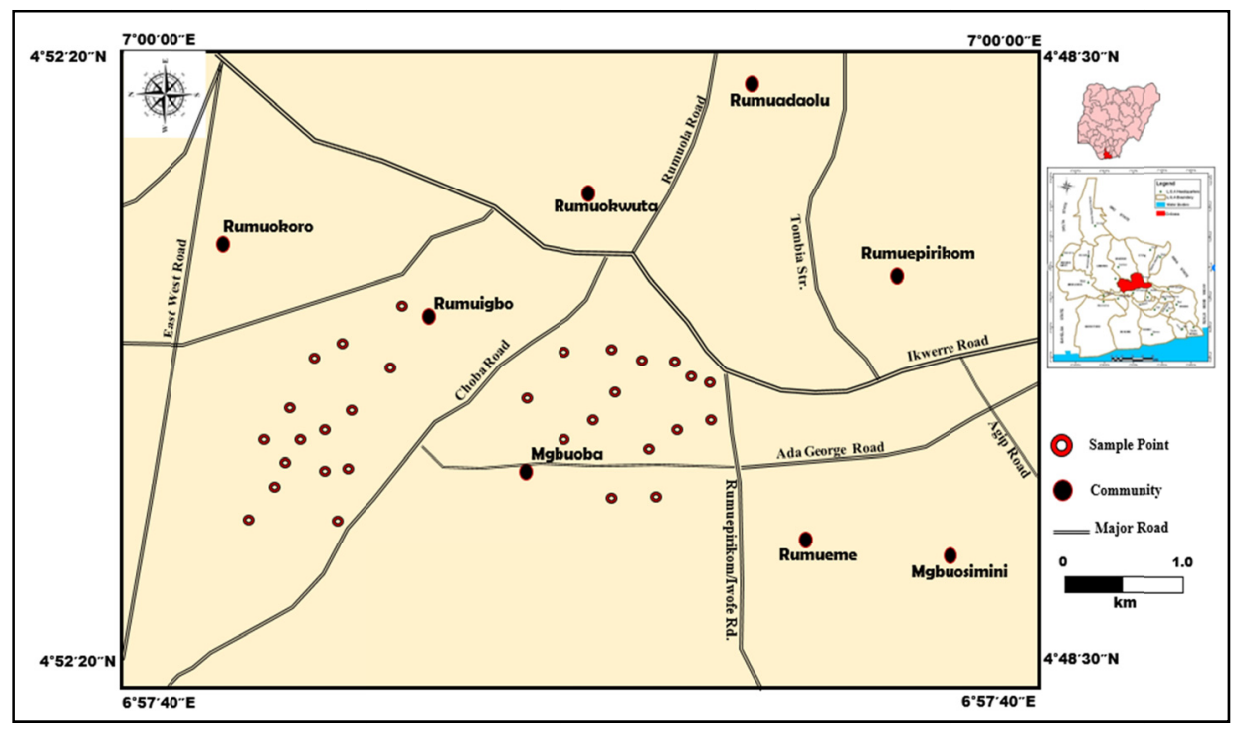

Figure 1. Map of the study area showing the sample location in Rumuigbo and Mgbuoba communities

\section{Methods of Study}

\subsection{Flood Height Measurements}

The flood heights were measured from marking on the walls of buildings, gates and fences (Figure 2). The current flood levels were measured from the ground surface to the top of the water surface (in $\mathrm{cm}$ ). The flood marks on structures which were higher than the current flood water level accounted for the highest flood heights in the area. The geographic reference locations were recorded against each measurement station. A total of 15 flood height/flood markings were measured from each of the two communities, making a total of 30 measurements at both locations. The recede flood time was calculated after continuous monitoring of the flood heights at five (5) selected locations for 4 days (96 hour), with measurements taken every 24 hours at each community. During this period when measurements were taken to compute the flood recede time, no additional rainfall occurred and this was a necessary requirement for an accurate calculation to be made. The ground surface elevations above sea level could not be established at most flood height locations where flood water had covered the lands, hence, the elevations above sea level were extracted from google earth satellite imagery through a process called digital elevation modeling.

Table 1. Field sampling locations and geographic references within the study area

\begin{tabular}{lllll}
\hline Community & Sample Code & Easting $(\mathrm{m})$ & Northing $(\mathrm{m})$ & Surface Elevation $(\mathrm{m})$ \\
& $\mathrm{S} 1$ & 274994 & 537171 & 13.00 \\
& $\mathrm{~S} 2$ & 275390 & 537142 & 14.00 \\
& $\mathrm{~S} 3$ & 275331 & 537361 & 13.00 \\
& $\mathrm{~S} 4$ & 275003 & 537899 & 15.00 \\
& $\mathrm{~S} 5$ & 275188 & 537728 & 14.00 \\
& $\mathrm{~S} 6$ & 275321 & 537648 & 16.00 \\
& $\mathrm{~S} 7$ & 275543 & 537803 & 13.00
\end{tabular}




\begin{tabular}{|c|c|c|c|c|}
\hline & S8 & 275502 & 537548 & 18.00 \\
\hline & S9 & 275702 & 537650 & 17.00 \\
\hline & $\mathrm{S} 10$ & 275603 & 537386 & 14.00 \\
\hline & S11 & 275748 & 537180 & 19.00 \\
\hline & $\mathrm{S} 12$ & 276074 & 537453 & 18.00 \\
\hline & S13 & 276161 & 537241 & 18.00 \\
\hline & S14 & 276018 & 536868 & 15.00 \\
\hline & $\mathrm{S} 15$ & 276411 & 536816 & 17.00 \\
\hline \multirow{15}{*}{ 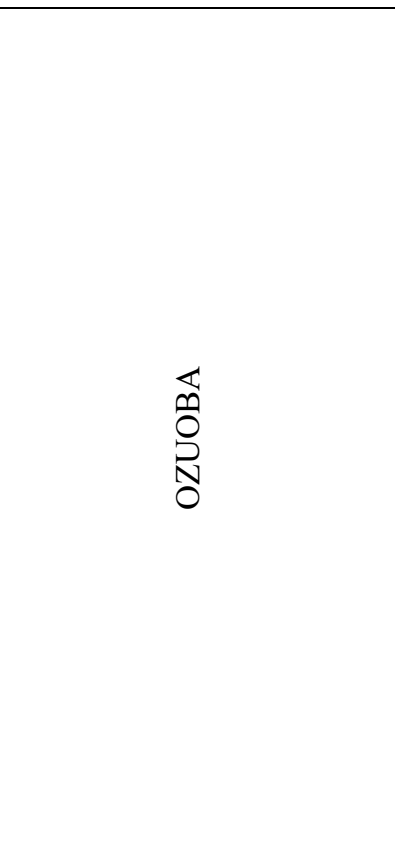 } & S16 & 276190 & 535564 & 24.00 \\
\hline & S17 & 275637 & 535471 & 22.00 \\
\hline & $\mathrm{S} 18$ & 275991 & 535123 & 26.00 \\
\hline & S19 & 275639 & 534832 & 22.00 \\
\hline & S20 & 276223 & 534652 & 26.00 \\
\hline & $\mathrm{S} 21$ & 275790 & 534602 & 25.00 \\
\hline & $\mathrm{S} 22$ & 276262 & 535159 & 22.00 \\
\hline & $\mathrm{S} 23$ & 275301 & 535095 & 26.00 \\
\hline & S24 & 275832 & 534364 & 25.00 \\
\hline & $\mathrm{S} 25$ & 276208 & 534916 & 24.00 \\
\hline & S26 & 275329 & 534751 & 26.00 \\
\hline & S27 & 275771 & 535277 & 24.00 \\
\hline & $\mathrm{S} 28$ & 275854 & 535794 & 23.00 \\
\hline & S29 & 276132 & 534517 & 24.00 \\
\hline & $\mathrm{S} 30$ & 276119 & 534380 & 26.00 \\
\hline Rumu-Oparali Control site & $\mathrm{S} 31$ & 277973 & 534065 & 53.00 \\
\hline Rumuadaolu Control site & $\mathrm{S} 32$ & 272630 & 536022 & 45.00 \\
\hline
\end{tabular}

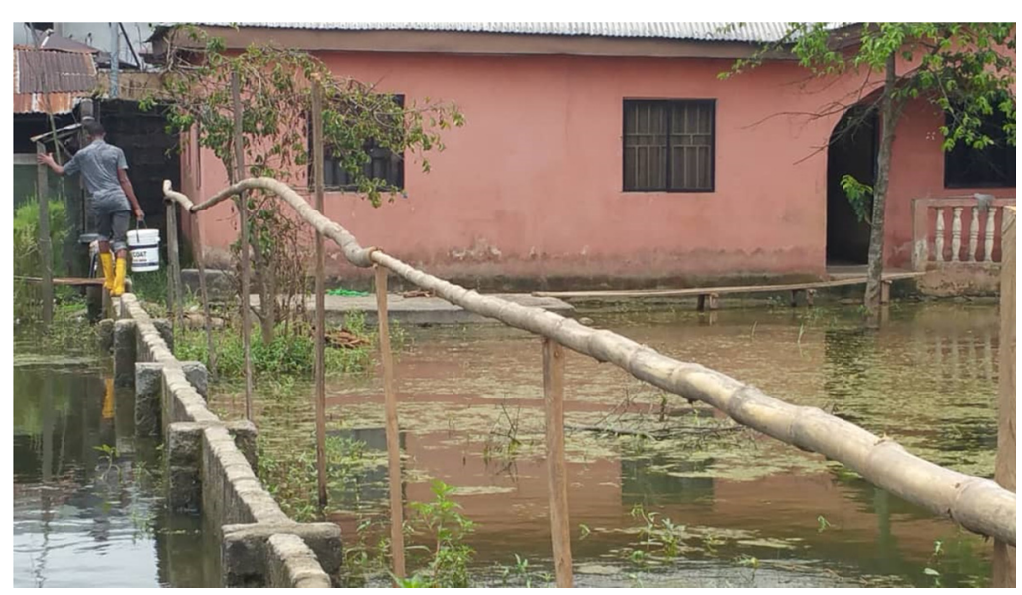



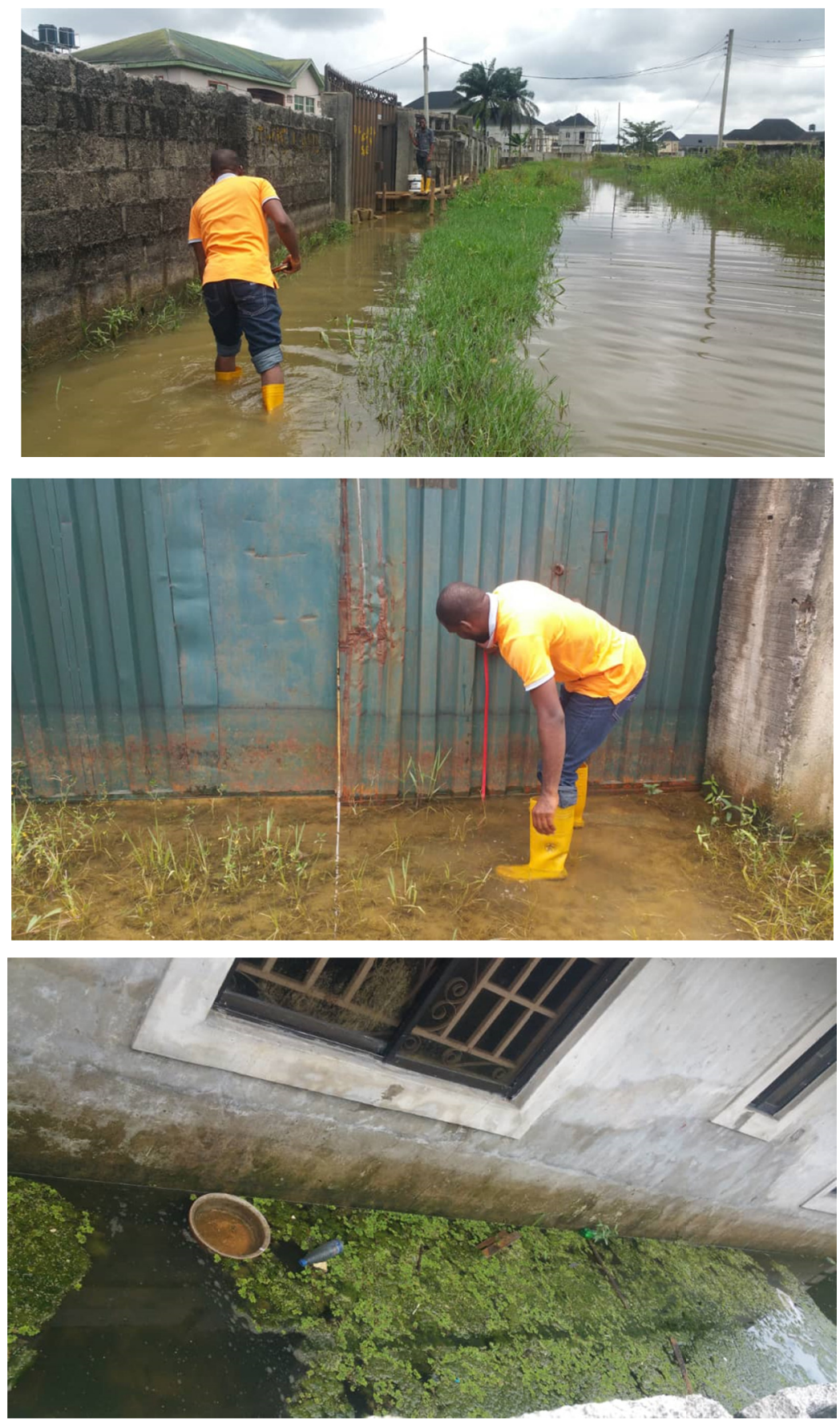

Figure 2. Flooding within the vicinity of the study area, (a) Flood mark on building wall in Rumuigbo (b) Flood mark on fence of building in Rumuigbo (c) Flood mark on gate of residential building in Rumuigbo (d) Flood mark on building wall in Ozuoba

\section{Result and Discussions}

The surface elevation in Rumuigbo area ranged from 13 to $19 \mathrm{~m}$ and from 22 to $26 \mathrm{~m}$ in Ozuoba area. At the control site, surface elevations are 45 and $53 \mathrm{~m}$ respectively (Table 1). These results show that Rumuigbo and Ozuoba communities are situated at a lower elevation than the surrounding environment. The highest flood mark recorded in the area ranged from 86 to $104 \mathrm{~cm}$ and 84 to $98 \mathrm{~cm}$ in Rumuigbo and Ozuoba communities. This suggests that a larger part of Rumuigbo is often submerged under water compared with Ozuoba area. Flood heights were monitored and measured daily for three days of continuous rainfall in the area. The results were used to calculate flood encroachment rates as presented in Table 2. The results show an encroachment rate which 
ranges from $9.47 \mathrm{~cm}$ to $19.67 \mathrm{~cm}$ in Rumuigbo and $6.47 \mathrm{~cm}$ to $9.00 \mathrm{~cm}$ in Ozuoba area. On average, the flood encroachment rate is $14.57 \mathrm{~cm}$ and $7.73 \mathrm{~cm}$ in Rumuigbo and Ozuoba areas respectively. These results show that the impact arising from rising flood level in Ozuoba is double when compared with Rumuigbo area. Also, the daily flood recede time was calculated after monitoring the decrease in flood heights in the area for three days. The daily flood recede rate ranged from $0.87 \mathrm{~cm}$ to $3.93 \mathrm{~cm}$ and $5.00 \mathrm{~cm}$ to $8.00 \mathrm{~cm}$ in Rumuigbo and Ozuoba areas. The average recede rates calculated for Rumuigbo and Ozuoba areas are $2.4 \mathrm{~cm} /$ day and $6.5 \mathrm{~cm} /$ day respectively (Table 2). The average difference between the highest flood mark on wall and highest current flood levels is $38.13 \mathrm{~cm}$ and $23.20 \mathrm{~cm}$ in Rumuigbo and Ozuoba areas. The results suggest that the effects recorded by flooding in the last quarter of 2018 are not the highest felt in these flood prone areas.

The study areas; Rumuigbo and Ozuoba communities are situated on a lower slope $(<26.0 \mathrm{~m})$ compared to the surrounding communities ( $>45.0 \mathrm{~m}$ ), thus, rainfall will always drain into these communities from surrounding communities and causing flooding because they act as a sink due to their low-lying topographies. Highest flood marks on walls, fences, gates and buildings in Rumuigbo and Ozuoba communities are relatively much higher than the current flood levels recorded, suggesting that they were periods in the past when flood incidents were much more intense in the area. In an earlier study conducted by Akpokodje (2007), flood marking on walls in Ozuoba area ranged from 70 to $150 \mathrm{~cm}$ as opposed to a range of $84-98 \mathrm{~cm}$ recorded in this study. This results as compared with earlier studies conducted in the area suggests that the flood incidents that caused the highest flood marks occurred in 2007.

The average flood encroachment rate recorded in this study showed that flood water levels rises by about 14.57 $\mathrm{cm} /$ day in Rumuigbo and $7.73 \mathrm{~cm} /$ day in Ozuoba area. This indicates that Rumuigbo stands a greater risk of being flooded compared to Ozuoba area because it will take roughly twice the amount of rainfall that floods Rumuigbo to cause flooding to occur in Ozuoba at significant levels. Based on these recorded encroachment rate, it becomes easy to quantify the flood heights after any given time, provided that the rains are continuous and heavy during this period.

Table 2. Results of flood heights measurement around Rumuigbo area

\begin{tabular}{|c|c|c|c|c|c|c|c|c|c|c|}
\hline \multirow[t]{2}{*}{$\mathrm{S} / \mathrm{N}$} & \multirow[t]{2}{*}{$\begin{array}{l}\text { Surface } \\
(\mathrm{m})\end{array}$} & \multirow[t]{2}{*}{ Elevation } & \multirow{2}{*}{$\begin{array}{l}\text { Highest } \\
\text { Marking } \\
\text { on wall }(\mathrm{cm})\end{array}$} & \multirow[t]{2}{*}{ Flood } & \multicolumn{3}{|c|}{$\begin{array}{l}\text { Flood Heights } \\
\text { (During Peak Rainfall) in } \\
\mathrm{cm}\end{array}$} & $\begin{array}{l}\text { Flood } \\
\text { in } \mathrm{cm}\end{array}$ & Height (After & \multirow{2}{*}{$\begin{array}{c}\text { Rainfall Stops) } \\
\text { Day } 3\end{array}$} \\
\hline & & & & & Day 1 & Day 2 & Day 3 & Day 1 & Day 2 & \\
\hline S1 & 13.00 & & 104.00 & & 33.00 & 42.00 & 68.00 & 60.00 & 57.00 & 57.00 \\
\hline S2 & 14.00 & & 101.00 & & 35.00 & 46.00 & 65.00 & 58.00 & 54.00 & 52.00 \\
\hline S3 & 13.00 & & 102.00 & & 32.00 & 41.00 & 62.00 & 56.00 & 50.00 & 50.00 \\
\hline S4 & 15.00 & & 97.00 & & 31.00 & 39.00 & 50.00 & 45.00 & 42.00 & 40.00 \\
\hline S5 & 14.00 & & 100.00 & & 36.00 & 48.00 & 68.00 & 60.00 & 57.00 & 56.00 \\
\hline S6 & 16.00 & & 89.00 & & 27.00 & 33.00 & 52.00 & 46.00 & 43.00 & 43.00 \\
\hline S7 & 13.00 & & 103.00 & & 30.00 & 41.00 & 65.00 & 60.00 & 55.00 & 53.00 \\
\hline S8 & 18.00 & & 90.00 & & 29.00 & 38.00 & 55.00 & 49.00 & 45.00 & 44.00 \\
\hline S9 & 17.00 & & 92.00 & & 25.00 & 37.00 & 58.00 & 51.00 & 47.00 & 47.00 \\
\hline S10 & 14.00 & & 98.00 & & 25.00 & 33.00 & 58.00 & 50.00 & 45.00 & 44.00 \\
\hline S11 & 19.00 & & 86.00 & & 28.00 & 39.00 & 60.00 & 57.00 & 52.00 & 52.00 \\
\hline S12 & 18.00 & & 88.00 & & 19.00 & 29.00 & 41.00 & 36.00 & 31.00 & 30.00 \\
\hline S13 & 18.00 & & 90.00 & & 28.00 & 35.00 & 53.00 & 47.00 & 44.00 & 44.00 \\
\hline S14 & 15.00 & & 92.00 & & 14.00 & 24.00 & 44.00 & 37.00 & 34.00 & 31.00 \\
\hline S15 & 17.00 & & 88.00 & & 19.00 & 28.00 & 49.00 & 41.00 & 38.00 & 38.00 \\
\hline
\end{tabular}


Table 3. Results of flood heights measurement around Ozuoba area

\begin{tabular}{|c|c|c|c|c|c|c|c|c|}
\hline \multirow[t]{2}{*}{$\mathrm{S} / \mathrm{N}$} & \multirow[t]{2}{*}{ Surface Elevation (m) } & \multirow{2}{*}{$\begin{array}{l}\text { Highest Flood Marking } \\
\text { on wall }(\mathrm{m})\end{array}$} & \multicolumn{3}{|c|}{ Flood Heights } & \multicolumn{3}{|c|}{ Flood Height } \\
\hline & & & Day 1 & Day 2 & Day 3 & Day 1 & Day 2 & Day 3 \\
\hline S16 & 24.00 & 92.00 & 45.00 & 52.00 & 58.00 & 49.00 & 40.00 & 35.00 \\
\hline S17 & 22.00 & 98.00 & 77.00 & 81.00 & 88.00 & 80.00 & 71.00 & 66.00 \\
\hline S18 & 26.00 & 90.00 & 62.00 & 70.00 & 76.00 & 68.00 & 60.00 & 54.00 \\
\hline S19 & 22.00 & 98.00 & 68.00 & 74.00 & 81.00 & 73.00 & 64.00 & 60.00 \\
\hline S20 & 26.00 & 92.00 & 58.00 & 65.00 & 73.00 & 64.00 & 53.00 & 50.00 \\
\hline S21 & 25.00 & 98.00 & 58.00 & 64.00 & 72.00 & 60.00 & 52.00 & 47.00 \\
\hline $\mathrm{S} 22$ & 22.00 & 95.00 & 44.00 & 50.00 & 68.00 & 59.00 & 50.00 & 44.00 \\
\hline $\mathrm{S} 23$ & 26.00 & 91.00 & 56.00 & 61.00 & 69.00 & 59.00 & 49.00 & 43.00 \\
\hline S24 & 25.00 & 91.00 & 50.00 & 58.00 & 65.00 & 54.00 & 44.00 & 40.00 \\
\hline S25 & 24.00 & 98.00 & 51.00 & 59.00 & 66.00 & 53.00 & 46.00 & 40.00 \\
\hline S26 & 26.00 & 87.00 & 49.00 & 55.00 & 62.00 & 54.00 & 45.00 & 39.00 \\
\hline S27 & 24.00 & 90.00 & 44.00 & 50.00 & 59.00 & 48.00 & 40.00 & 36.00 \\
\hline S28 & 23.00 & 95.00 & 52.00 & 60.00 & 72.00 & 60.00 & 51.00 & 46.00 \\
\hline S29 & 24.00 & 96.00 & 56.00 & 62.00 & 70.00 & 59.00 & 50.00 & 44.00 \\
\hline S30 & 26.00 & 84.00 & 45.00 & 51.00 & 68.00 & 58.00 & 48.00 & 44.00 \\
\hline
\end{tabular}

Table 4. Results of statistical analysis performed on flood height markings

\begin{tabular}{|c|c|c|c|c|c|c|c|}
\hline \multirow{2}{*}{ Flood Parameters } & & \multicolumn{3}{|c|}{ Rumuigbo Area } & \multicolumn{3}{|c|}{ Ozuoba Area } \\
\hline & & Min & Max & Mean & Min & Max & Mean \\
\hline \multicolumn{2}{|l|}{ Surface Elevation (m) } & 13.00 & 19.00 & 15.60 & 22.00 & 26.00 & 24.33 \\
\hline \multicolumn{2}{|l|}{ Highest Flood Mark (cm) } & 86.00 & 104.00 & 94.67 & 84.00 & 98.00 & 93.00 \\
\hline \multirow[t]{3}{*}{ Flood Heights (During Rainfall) $(\mathrm{cm})$} & Day 1 & 14.00 & 36.00 & 27.40 & 44.00 & 77.00 & 54.33 \\
\hline & Day 2 & 24.00 & 48.00 & 36.87 & 50.00 & 81.00 & 60.80 \\
\hline & Day 3 & 41.00 & 68.00 & 56.53 & 58.00 & 88.00 & 69.80 \\
\hline \multirow[t]{3}{*}{ Flood Height (After Rainfall Stops) (m) } & Day 1 & 36.00 & 60.00 & 50.20 & 48.00 & 80.00 & 59.87 \\
\hline & Day 2 & 31.00 & 57.00 & 46.27 & 40.00 & 71.00 & 50.87 \\
\hline & Day 3 & 30.00 & 57.00 & 45.40 & 35.00 & 66.00 & 45.87 \\
\hline \multicolumn{2}{|l|}{ Flood Daily Encroachment Rate (m) } & 9.47 & 19.67 & 14.57 & 6.47 & 9.00 & 7.73 \\
\hline \multicolumn{2}{|l|}{ Flood Daily Recede Rate (m) } & 0.87 & 3.93 & 2.40 & 5.00 & 8.00 & 6.50 \\
\hline \multicolumn{2}{|c|}{ Highest Flood Marking on wall - Highest current flood height (m) } & 36.00 & 45.00 & 38.13 & 10.00 & 26.00 & 23.20 \\
\hline
\end{tabular}




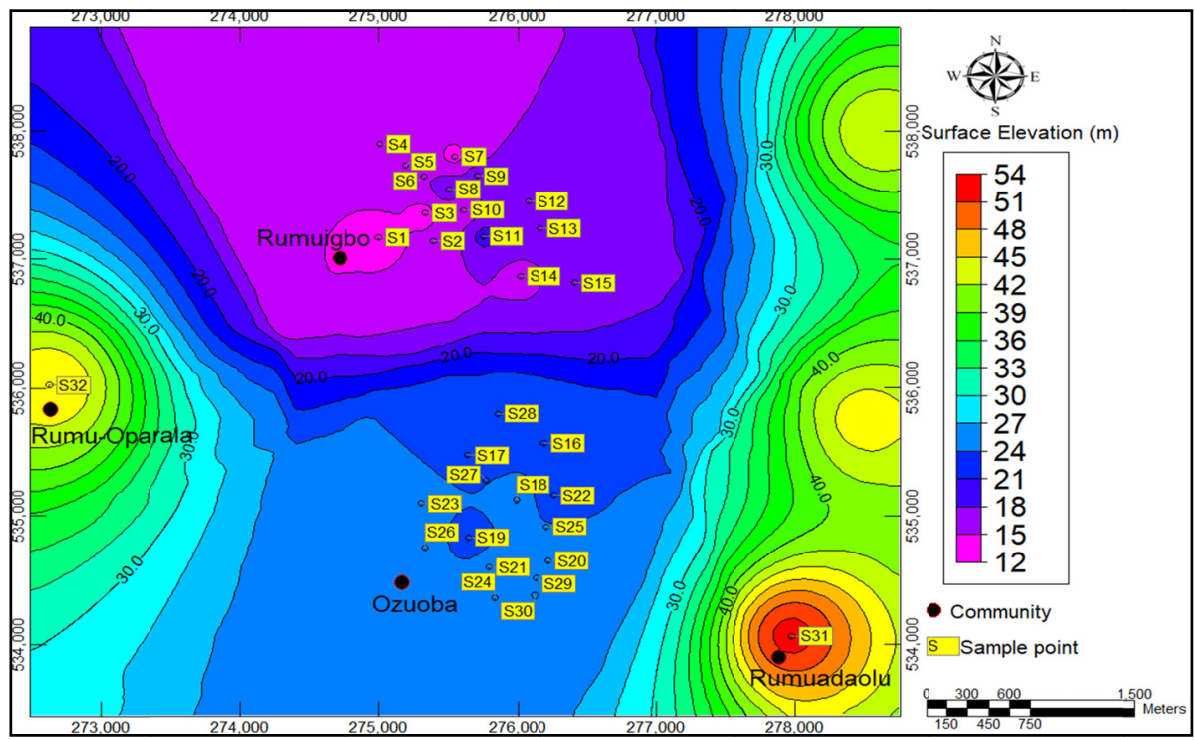

Figure 2. Surface Elevation acquired from field studies within the study area

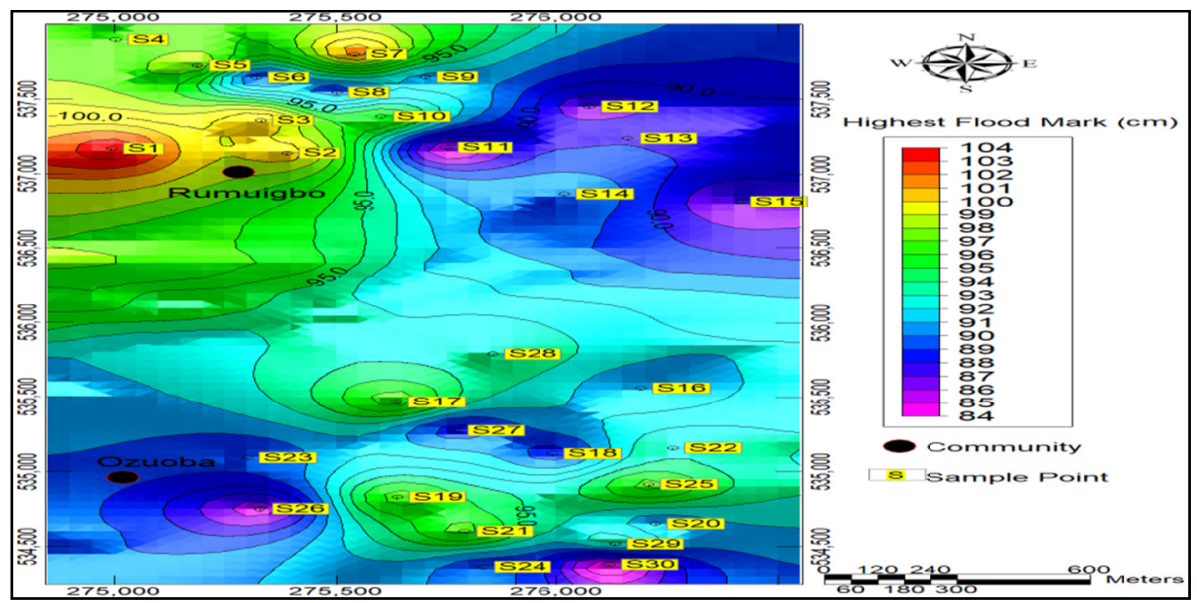

Figure 3. Flood Markings acquired from fences and building walls in the study area

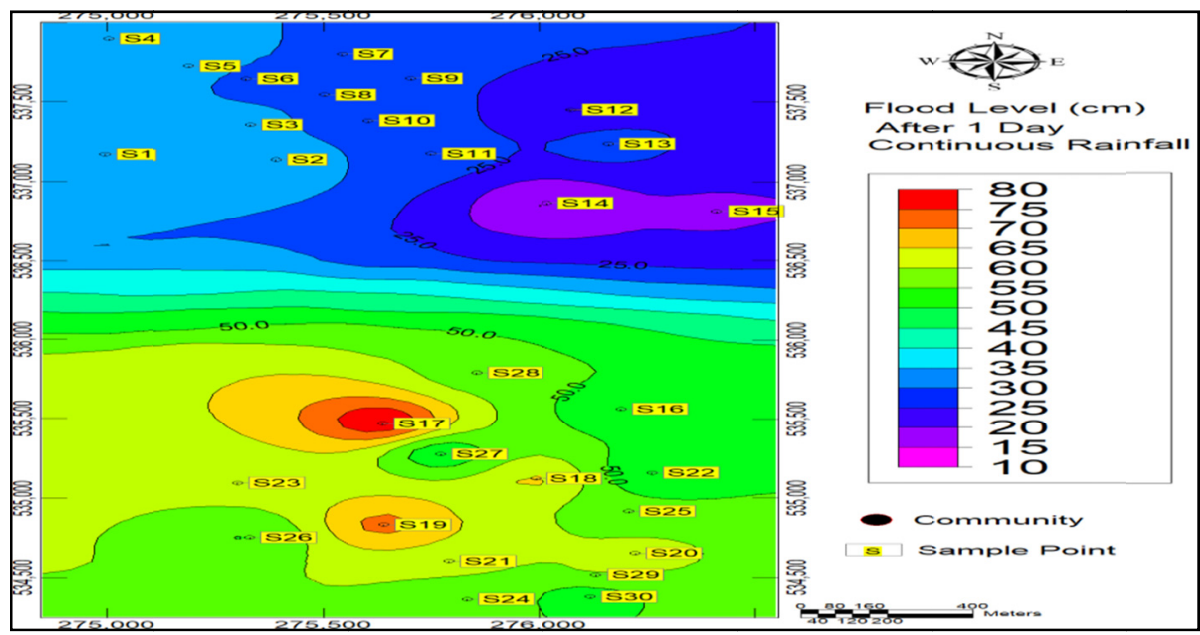

Figure 4. Flood height after 1 day of continuous rainfall in the study area 


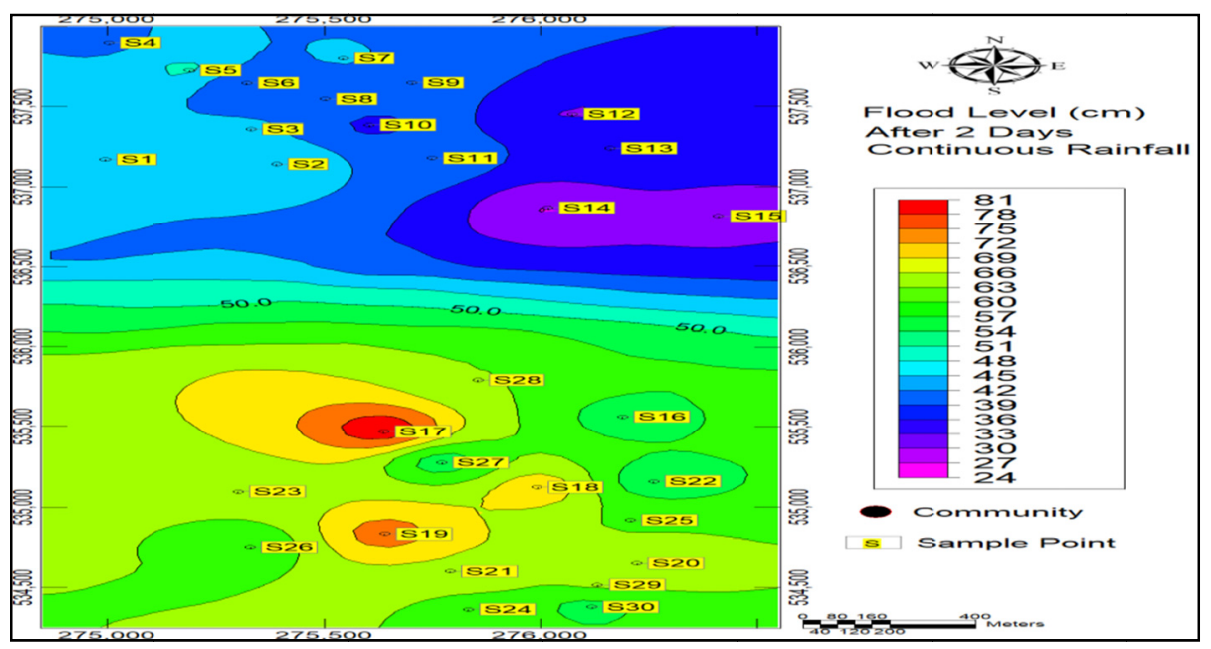

Figure 5. Flood height after 2 days of continuous rainfall in the study area

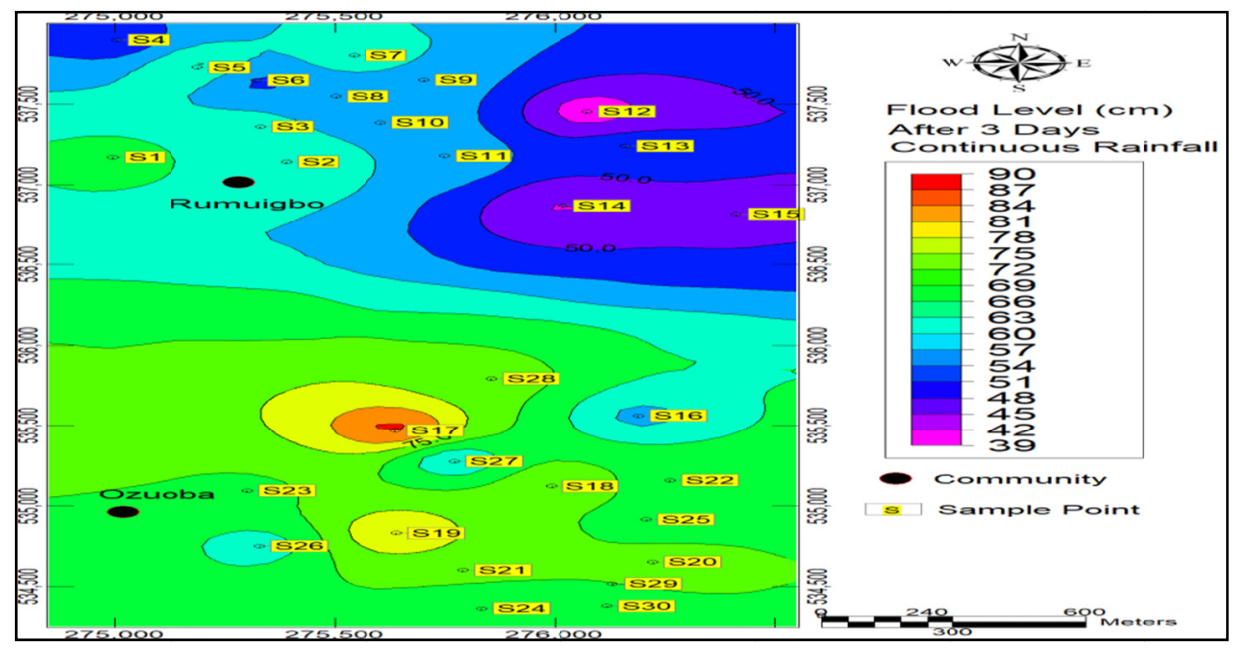

Figure 6. Flood height after 3 days of continuous rainfall in the study area

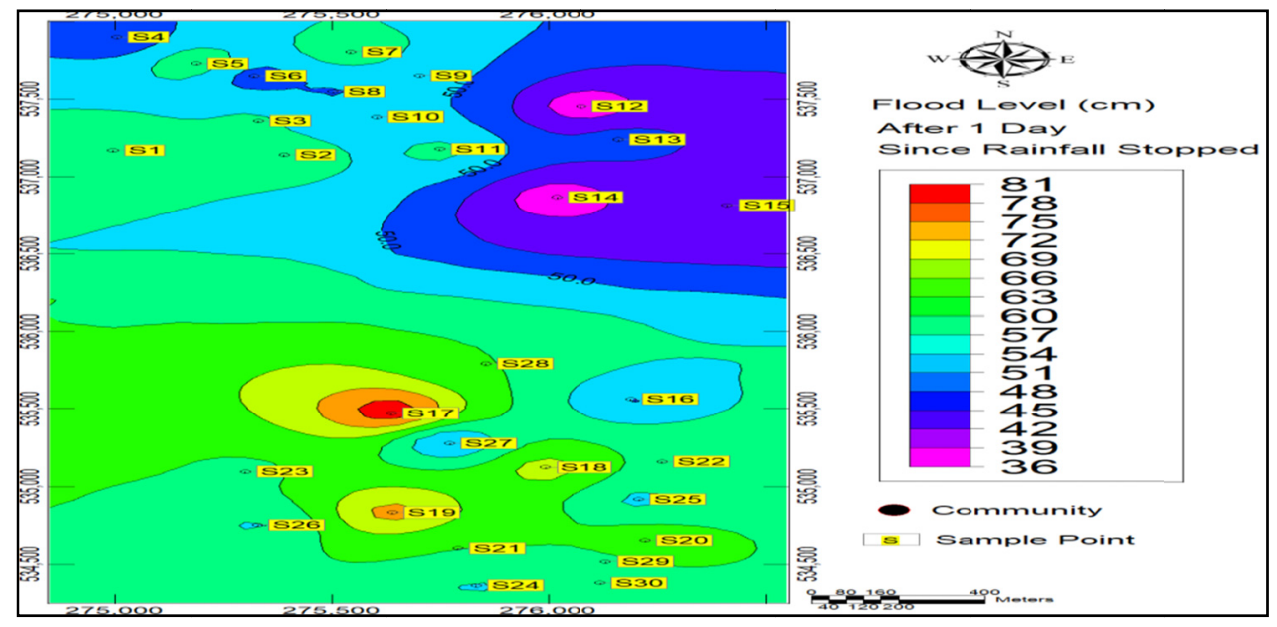

Figure 7. Flood height after 1 day since rainfall stopped in the study area 


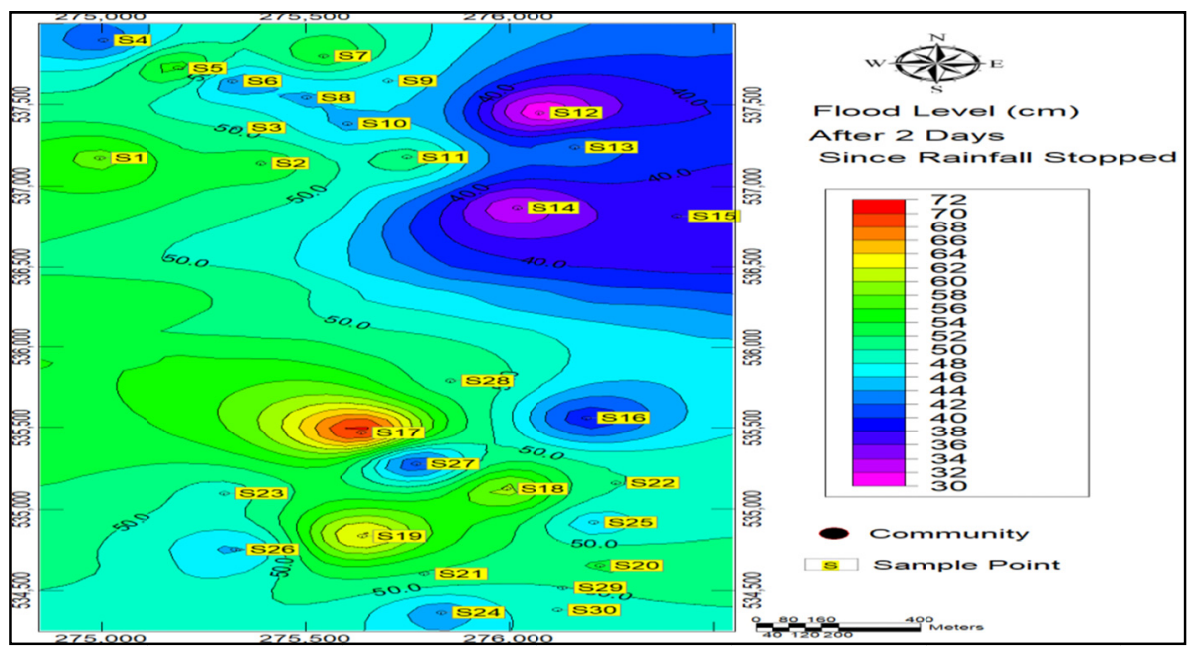

Figure 8. Flood height after 2 days since rainfall stopped in the study area

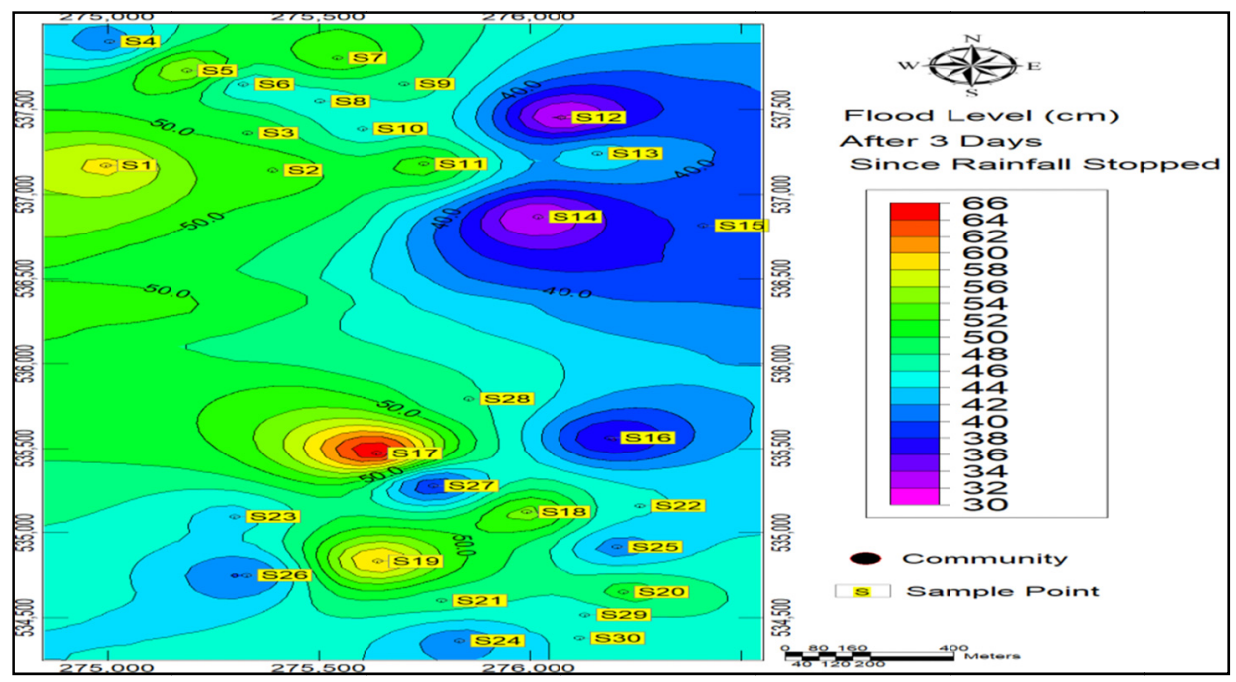

Figure 9. Flood height after 3 days since rainfall stopped in the study area

\section{Conclusion}

Field studies involved flood height and flood marks measurement and soil sampling at $0 \mathrm{~m}, 1.0 \mathrm{~m}, 2.0 \mathrm{~m}$ and $3.0 \mathrm{~m}$, respectively. Thirty (30) locations were selected for flood height measurements and soil sampling, while two communities were selected as the control areas which were devoid of flood incidents. Flood height analysis was used to estimate the flood encroachment rate and flood receding rates.

The results showed that Rumuigbo area suffers high flood rise compared to Ozuoba area because of the type of soils, moisture content and permeability of the soils. Ozuoba soils are sandier, with lower moisture content and higher permeability values compared with Rumuigbo soils. Similarly, the daily recede rate reveals that Ozuoba soils take a shorter time to get completely dry compared to Rumuigbo area. Flood encroachment and recede rates are $14.57 \mathrm{~cm} /$ day and $2.4 \mathrm{~cm} /$ day in Rumuigbo and $7.73 \mathrm{~cm} /$ day and $6.5 \mathrm{~cm} /$ day in Ozuoba area respectively. The control sites have better soil quality and are situated at a higher topography than Rumuigbo and Ozuoba communities. Rumuigbo area is highly vulnerable to flooding when compared with Ozuoba area where the soils are moderately to highly vulnerable to flooding. The study has shown how flood height monitoring can be used to quantify flood encroachment rate and flood recede rates in any given area. Also, from these encroachment rates and recede rates, forecast into the future regarding flood levels can be made for any given time, provided that rainfall is continuous and heavy during these days. Large sloping gutters should be constructed within strategic places in the area in order to properly transport flood water to the nearby rivers. Proper sensitization should be conducted for residents of flood prone areas so they can know what to do in the event of another flood 
incident.

\section{References}

Akpokodje, E. (2007). A Colloquium Paper Presented on Flood Risk Assessment at the National Association of Hydrogeologist, Conference, Port Harcourt, Abstract Volume.

Chiadikobi, K. C., Omoboriowo, A. O., Chiaghanam, O. I., Opatola, A. O., \& Oyebanji, O. (2011). Flood Risk Assessment of Port Harcourt, Rivers State, Nigeria. Advances in Applied Science Research, 2(6), 287-298.

Etuonovbe, A. K. (2011). The Devastating Effect of Flooding in Nigeria. Hydrography and the Environment Innocent Chirisa, Zimbabwe Inclusive Cities and Housing: Analysis of stewardship instruments in Epworth, Zimbabwe FIG Working Week. Bridging the Gap between Cultures Marrakech, Morocco.

Igbokwe, J. I., Akinyede, J. O., Dang, B., Alaga, T., Ono, M. N., Nnodu, V. C., \& Anike, L. O. (2008). Mapping and Monitoring the Impacts of Flood and Erosion in South Eastern Nigeria with Satellite Remote Sensing and Geographic Information System. Int. Arch. Photogramm. Remote Sens. Spat. Inf. Sci., 37, 865-872.

Jeb, D. N., \& Aggarwal, S. P. (2008). Flood in Inundation Hazard Modelling of the River Kaduna using Remote Sensing and Geographic Information Systems. Jouranal of Applied Sciences Research, 4(12), 1822-1833.

Kolawole, O. M., Olayemi, A. B., \& Ajayi, K. T. (2011). Managing Flood in Nigerian Cities: Risk Analysis and Adaptation Options - Ilorin as a Case Study. Scholars Research Library, 3(1), 17-24.

OECD. (2012). Environmental Outlook to 2050. The Consequences of Inaction (Paris: OECD). https://doi.org/10.1787/9789264122246-en

Onwuka, S. U., Ikekpeazu, F. O., \& Onuoha, D. C. (2015). Assessment of the Causes of 2012 Floods in Aguleri and Umuleri, Anambra East Local Government Area of Anambra State, Nigeria. Eff. Br. Mindfulness Interv. Acute Pain Exp. An Exam. Individ. Differ., 1, 1689-1699.

UNOCHA. (2012). Overview: Impact of Floods West and Central Africa; United Nations Office for the Coordination of Humanitarian Affairs: Abuja, Nigeria, 2012.

UNOCHA. (2015). Humanitarian Bulletin Nigeria; United Nations Office for the Coordination of Humanitarian Affairs: Abuja, Nigeria, 2015.

\section{Copyrights}

Copyright for this article is retained by the author(s), with first publication rights granted to the journal.

This is an open-access article distributed under the terms and conditions of the Creative Commons Attribution license (http://creativecommons.org/licenses/by/4.0/). 